\title{
Estimation of Leaf Area of Jackfruit Through Non-destructive Method
}

\author{
Vinicius de Souza Oliveira ${ }^{1}$, Leonardo Raasch $\mathrm{Hell}^{2}$, Karina Tiemi Hassuda dos Santos ${ }^{3}$, \\ Hugo Rebonato Pelegrini ${ }^{3}$, Jéssica Sayuri Hassuda Santos ${ }^{3}$, Graziela Evencio de Oliveira ${ }^{3}$, \\ Adriel Lima Nascimento ${ }^{4}$, Gleyce Pereira Santos ${ }^{3}$, Omar Schmildt 1 , Marcio Paulo Czepak ${ }^{3}$, \\ Sara Dousseau Arantes ${ }^{5}$, Rodrigo Sobreira Alexandre ${ }^{4} \&$ Edilson Romais Schmildt ${ }^{3}$ \\ ${ }^{1}$ Postgraduate Program in Tropical Agriculture, Federal University of Espírito Santo, São Mateus, ES, Brazil \\ ${ }^{2}$ Federal Institute of Espírito Santo, Campus Itapina, Colatina, Espírito Santo, Brazil \\ ${ }^{3}$ Departament of Agrarian and Biological Sciences, Federal University of Espírito Santo, São Mateus, ES, Brazil \\ ${ }^{4}$ Federal University of Espírito Santo, Alegre, ES, Brazil \\ ${ }^{5}$ Capixaba Institute for Research, Technical Assistance and Rural Extension, Regional Center for Rural \\ Development, Brazil \\ Correspondence: Vinicius de Souza Oliveira, Postgraduate Program in Tropical Agriculture, Federal University \\ of Espírito Santo, São Mateus, ES, Brazil. E-mail: souzaoliveiravini@gmail.com
}

Received: February 25, 2019 Accepted: March 28, 2019 Online Published: May 15, 2019

doi:10.5539/jas.v11n6p77 URL: https://doi.org/10.5539/jas.v11n6p77

\begin{abstract}
The objective of this study was to determine mathematical equations that estimate the leaf area of jackfruit (Artocarpus heterophyllus) in an easy and non-destructive way based on linear dimensions. In this way, 300 leaves of different sizes and in good sanitary condition of adult plants were collected at the Federal Institute of Espírito Santo, Campus Itapina, located in Colatina, municipality north of the State of Espírito Santo, Brazil. Were measured The length (L) along the midrib and the maximum leaf width (W), observed leaf area (OLA), besides the product of the multiplication of length with width (LW), length with length (LL) and width with width (WW). The models of linear equations of first degree, quadratic and power and their respective $\mathrm{R}^{2}$ were adjusted using OLA as dependent variable in function of L, W and LW, LL and WW as independent variable. The data were validated and the estimated leaf area (ELA) was obtained. The means of ELA and OLA were compared by Student's t test (5\% probability) and were evaluated by the mean absolute error (MAE) and root mean square error (RMSE) criteria. The choice of the best model was based on non-significant comparative values of ELA and OLA, in addition to the closest values of zero of EAM and RQME. The jackfruit leaf area estimate can be determined quickly, accurately and non-destructively by the linear first-order model with LW as the independent variable by equation ELA $=1.07451+0.71181(\mathrm{LW})$.
\end{abstract}

Keywords: Artocarpus heterophyllus, linear dimensions, mathematical equations

\section{Introduction}

The jackfruit (Artocarpus heterophyllus) belonging to the family Moraceae, is a species native to India, introduced in Brazil during the colonial period, where the edaphoclimatic conditions were well adapted. Its use varies in the most diverse forms, from the consumption of the fruit in natura or processed, to the medical industry, presenting great economic potential for the internal and external market (Perdomo \& Magalhães, 2007; Oliveira, Godoy, \& Borges, 2011).

The knowledge of the leaf area is of paramount importance in physiological studies, involving photosynthetic apparatus efficiency, transpiration and response to irrigation and fertilizers, being an essential characteristic in the analysis of plant growth and development (Blanco \& Folegatti, 2005; Morgado et al., 2013).

The leaf area can be determined by direct or indirect methods. The direct methods, however precise, require high labor, specific and expensive equipment, besides being destructive, making impossible measurements on the same leaf (Pompelli et al., 2012). The indirect methods are non-destructive and easy to execute, allowing the researcher to make successive measurements on the same leaf, being able to estimate the leaf area accurately over time (Peaksen, 2007; Oliveira, Silva, Costa, Schmildt, \& Vitória, 2017).

A of the indirect methods most used to estimate the leaf area of plant species is through mathematical equations. 
These models involve linear measures such as length and leaf width, or the combination of these variables, presenting good precision, however they need to be adjusted previously (Costa, Pôças, \& Cunha, 2016).

Models that estimate the leaf area of several fruit species have been proposed as para Vitis vinifera L. (Montero, Juan, Cuesta, \& Brasa 2000; Borghezan, Gavioli, Pit, \& Silva, 2010; Buttaro, Rouphael, Rivera, Colla, \& Gonnella, 2015), Carica papaya L. (Campostrini \& Yamanishi, 2001), Passiflora mucronata (Schmildt, Oliari, Schmildt, Alexandre, \& Pires, 2016), Litchi chinensis Sonn (Oliveira et al., 2017) and guava (Vitória et al., 2018).

However, the studies that involve Artocarpus heterophyllus are lacking, being fundamental the emergence of new technologies for the advancement of the exploration of the culture. Thus, the objective of the present work was to determine mathematical models to estimate the leaf area of Artocarpus heterophyllus, in an easy and non-destructive way, based on linear dimensions.

\section{Method}

For the determination of the leaf area were used leaves of jackfruit of the Federal Institute of Espírito Santo, Campus Itapina, Colatina, municipality north of the State of Espírito Santo, Brazil, located at latitude 19'32'22" and longitude $40^{\circ} 37^{\prime} 50^{\prime \prime}$ West. The climate of the region according to the classification of Köppen is Tropical Aw (Köppen, 1936).

Fifteen adult plants were used, with 20 leaves per plant of different sizes and in good sanitary condition, totaling 300 leaves in the study, 250 of which were used to estimate the modeling and 50 were used to validate the data. The leaves were stored in plastic bags and transported to the Plant Improvement Laboratory of the University of Espírito Santo (UFES), located in the municipality of São Mateus, Espírito, Santo, Brazil.

In the lab, the sheets were scanned in HP Deskjet $F 4280^{\circledR}$ Scanner and the images are saved in TIF format with 75 dpi. The length (L) along the midrib and the maximum leaf width (W) in $\mathrm{cm}$ (Figure 1), as well as the observed leaf area (OLA, $\mathrm{cm}^{2}$ ) were measured in the Image $\mathrm{J}^{\circledR}$ program (Schindelin, Rueden, Hiner, \& Eliceiri, 2015). The product of length multiplication with width (LW), length with length (LL) and width with width (WW) was also obtained.

L

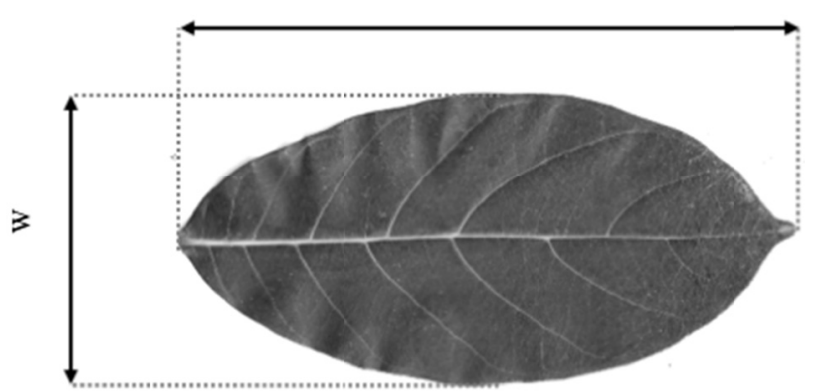

Figure 1. Representation of the length (L) along the midrib and the maximum leaf width (W) of Artocarpus heterophyllus

Descriptive statistics were analyzed, obtaining the minimum, maximum, mean and coefficient of variation (CV) values of L, W, LW, LL and WW. The estimation of the equations was based on the use of linear models of first degree, quadratic and power as shown in Table 1, where OLA was used with dependent variable as function of L, W, LW, LL and WW. Thus, we obtained fifteen equations that estimate the leaf area of jackfruit and their respective coefficient of determination $\left(\mathrm{R}^{2}\right)$.

Table 1. Denomination and representation of equation models adjusted for Artocarpus heterophyllus leaf area estimation

\begin{tabular}{ll}
\hline Denomination & Representation \\
\hline Linear & ELA $=\hat{\beta}_{0}+\hat{\beta}_{1} x$ \\
Quadratic & ELA $=\hat{\beta}_{0}+\widehat{\beta}_{1} x+\widehat{\beta}_{2} x^{2}$ \\
Power & ELA $=\widehat{\beta}_{0} x^{\hat{\beta}_{1}}$ \\
\hline
\end{tabular}


Subsequently, the models were validated using a sample of 50 sheets specially designed for this purpose. The values of L, W, LW, LL and WW of each leaf were replaced in the equations proposed by the modeling, from where the estimated leaf area (ELA) was obtained, in $\mathrm{cm}^{2}$. A simple linear equation represented by and its respective coefficient of determination $\left(\mathrm{R}^{2}\right)$ was adjusted for each model, in which the ELA values represented the dependent variable as a function of OLA as an independent variable. The means obtained from ELA and OLA were compared by Student's t-test with a 5\% probability. The mean absolute error (MAE) and the root mean square error (RMSE) were also determined for all equations by means of the Equations 1 and 2:

$$
\begin{aligned}
\text { MAE } & =\frac{1}{n-1} \sum_{\mathrm{i}=1}^{\mathrm{n}}|\mathrm{ELA}-\mathrm{OLA}| \\
\mathrm{RMSE} & =\sqrt{\frac{1}{\mathrm{n}-1} \sum_{\mathrm{i}=1}^{\mathrm{n}}(\mathrm{ELA}-\mathrm{OLA})^{2}}
\end{aligned}
$$

Where, ELA is the estimated leaf area; OLA, the observed leaf area; $n$ is the total number of leaves used for validation, $\mathrm{n}=50$ in the present study.

The best model to estimate leaf area of jackfruit was defined based on the non-significant values between ELA and OLA, EAM and RQME values closer to zero, as well as higher coefficient of determination $\left(\mathrm{R}^{2}\right)$ of the equations. The statistical analysis was performed with the help of software R (R Core Team, 2018), through the data package ExpDes.pt version 1.2 (Ferreira, Cavalcanti, \& Nogueira, 2018).

\section{Results and Discussion}

Table 2 shows the descriptive analysis of Artocarpus heterophyllus leaf samples used for modeling and validation. It was verified that for the length (L) there was variation from 3.17 to $25.70 \mathrm{~cm}$, with a mean of 15.57 $\mathrm{cm}$ and an amplitude of $22.53 \mathrm{~cm}$. The width (W) had variation of 1.88 to $13.90 \mathrm{~cm}$, average of $7.81 \mathrm{~cm}$ and amplitude of $12.02 \mathrm{~cm}$. The product of length and width (LW) ranged from 6.09 to $357.23 \mathrm{~cm}^{2}$, with a mean of $136.01 \mathrm{~cm}^{2}$ and an amplitude of $351.23 \mathrm{~cm}^{2}$. The product of length and length (LL) ranged from 10.05 to 660.49 $\mathrm{cm}^{2}$, with a mean of $273.37 \mathrm{~cm}^{2}$, with an amplitude of $650.44 \mathrm{~cm}^{2}$. The product of width and width (WW) varied from 3.53 to $193.21 \mathrm{~cm}^{2}$, average of $68.39 \mathrm{~cm}^{2}$ and amplitude of $189.68 \mathrm{~cm}^{2}$. The observed leaf area (OLA) ranged from 5.09 to $250.52 \mathrm{~cm}^{2}$, with a mean of $97.88 \mathrm{~cm}^{2}$ and an amplitude of $246.08 \mathrm{~cm}^{2}$. These measures are very close to the measures of the sample used for the validation, since they should not exceed the measures used to propose the mathematical models (Levine, Stephan, \& Szabat, 2017).

Note that for all measurements the values of the coefficient of variation (CV) for both the sample of the leaves used for the modeling, and for the samples used for the validation was higher than $30 \%$ and is classified by Pimentel-Gomes (2009) as very high. However, this high variability is desirable when determining the mathematical equations for the estimation of the leaf area of plant species, since they represent the use of large, medium and small leaves, being representative all the development of the plant and generating more precise models for all phenological stages of the species (Pezzini et al., 2018).

Table 2. Minimum, maximum, mean, amplitude and coefficient of variation (CV) values of length (L), width (W), product of length with width (LW), product of length and length (LL), product of width with width (WW)

\begin{tabular}{|c|c|c|c|c|c|c|}
\hline Variable & Unity & Minimum & Maximum & Mean & Amplitude & $\mathrm{CV}(\%)$ \\
\hline \multicolumn{7}{|c|}{250 leaves used in modeling } \\
\hline $\mathrm{L}$ & $\mathrm{cm}$ & 3.17 & 25.70 & 15.57 & 22.53 & 35.64 \\
\hline W & $\mathrm{cm}$ & 1.88 & 13.90 & 7.81 & 12.02 & 34.68 \\
\hline LW & $\mathrm{cm}^{2}$ & 6.09 & 357.23 & 136.01 & 351.23 & 55.70 \\
\hline LL & $\mathrm{cm}^{2}$ & 10.05 & 660.49 & 273.37 & 650.44 & 56.16 \\
\hline WW & $\mathrm{cm}^{2}$ & 3.53 & 193.21 & 68.39 & 189.68 & 57.07 \\
\hline OLA & $\mathrm{cm}^{2}$ & 4.44 & 250.52 & 97.88 & 246.08 & 55.25 \\
\hline \multicolumn{7}{|c|}{50 leaves used in validation } \\
\hline $\mathrm{L}$ & $\mathrm{cm}$ & 3.79 & 19.30 & 11.17 & 15.51 & 43.17 \\
\hline W & $\mathrm{cm}$ & 1.90 & 11.93 & 6.36 & 10.03 & 45.29 \\
\hline LW & $\mathrm{cm}^{2}$ & 7.20 & 225.72 & 84.36 & 218.52 & 75.52 \\
\hline LL & $\mathrm{cm}^{2}$ & 14.36 & 372.49 & 147.48 & 358.13 & 75.55 \\
\hline WW & $\mathrm{cm}^{2}$ & 3.61 & 142.32 & 48.56 & 138.71 & 76.24 \\
\hline OLA & $\mathrm{cm}^{2}$ & 5.09 & 165.29 & 60.56 & 160.20 & 75.59 \\
\hline
\end{tabular}
and observed leaf area (OLA) of leaves of Artocarpus heterophyllus 
Table 3 shows the adjusted equations as well as their respective coefficients of determination $\left(\mathrm{R}^{2}\right)$ proposed to estimate the leaf area of Artocarpus heterophyllus. With the exception of first degree linear model equations based on $\mathrm{L}$ and $\mathrm{W}$, all other models presented $\mathrm{R}^{2}$ values above 0.95 , a value that according to Borghezan et al. (2010) indicates high precision in the estimation of mathematical models. However, the equations that had LW as independent variable showed higher values of $\mathrm{R}^{2}$, surpassing 0.99 . These results are superior to those found by Peksen (2007) and Oliveira et al. (2017) who verified good adjustments of the leaf area as a function of the product of length and width.

Table 3. Equation with linear adjustment of first degree, quadratic and power and its respective coefficient of determination (R2) using the observed leaf area (OLA) as dependent variable, as a function of length (L), width $(\mathrm{W})$, product of length with width (LW), product of length with length (LL), product of width with width (WW) of leaves of Artocarpus heterophyllus

\begin{tabular}{lll}
\hline Model & Equation & $\mathrm{R}^{2}$ \\
\hline Linear & ELA $=-48.2809+9.3831(\mathrm{~L})$ & 0.9282 \\
Linear & ELA $=-53.991+19.434(\mathrm{~W})$ & 0.9487 \\
Linear & ELA $=1.07451+0.71181(\mathrm{LW})$ & 0.9944 \\
Linear & ELA $=3.76891+0.34428(\mathrm{LL})$ & 0.9555 \\
Linear & ELA $=5.13685+1.35617(\mathrm{WW})$ & 0.9580 \\
Quadratic & ELA $=-3.57792+1.24872(\mathrm{~L})+0.30000(\mathrm{~L})^{2}$ & 0.9561 \\
Quadratic & ELA $=-18.37012+7.43935(\mathrm{~W})+0.84979(\mathrm{~W})^{2}$ & 0.9634 \\
Quadratic & ELA $=-0.56777690+0.74776782(\mathrm{LW})-0.00013413(\mathrm{LW})^{2}$ & 0.9947 \\
Quadratic & ELA $=1.71142494+0.36765650(\mathrm{LL})-0.00004411(\mathrm{LL})^{2}$ & 0.9559 \\
Quadratic & $\mathrm{ELA}=-2.0395368+1.6495871(\mathrm{WW})-0.0020810(\mathrm{WW})^{2}$ & 0.9632 \\
Power & $\mathrm{ELA}=0.5180(\mathrm{~L})^{1.8726}$ & 0.9560 \\
Power & $\mathrm{ELA}=2.2783(\mathrm{~W})^{1.7911}$ & 0.9606 \\
Power & $\mathrm{ELA}=0.8150(\mathrm{LW})^{0.9758}$ & 0.9946 \\
Power & $\mathrm{ELA}=0.5180(\mathrm{LL})^{0.9363}$ & 0.9560 \\
Power & $\mathrm{ELA}=2.2783(\mathrm{WW})^{0.8955}$ & 0.9606 \\
\hline
\end{tabular}

In Figure 2, first degree linear equations for the validation of the data and their respective determination coefficients $\left(\mathrm{R}^{2}\right)$ are represented. Note that the highest value of $\mathrm{R}^{2}$ was found in the first degree linear equation based on LW (Figure $2 \mathrm{G}$ ), showing that $99.88 \%$ of the estimated leaf area is explained by the leaf area observed, indicating a high correlation between ELA and OLA for this equation. However, the linear adjustment of first degree did not present the best value of $\mathrm{R}^{2}$ in the modeling equation, having lower values than the quadratic models and also power based on LW. However, according to Antunes, Pompelli, Carretero, and Damatta (2018), the model should not be proposed only for its high value of $\mathrm{R}^{2}$, since this practice can lead to erroneous estimations of the leaf area. Thus, validation of data is fundamental as a criterion of choice for the best model to be adopted (Fascella, Darwich, \& Rouphael, 2013). 
A

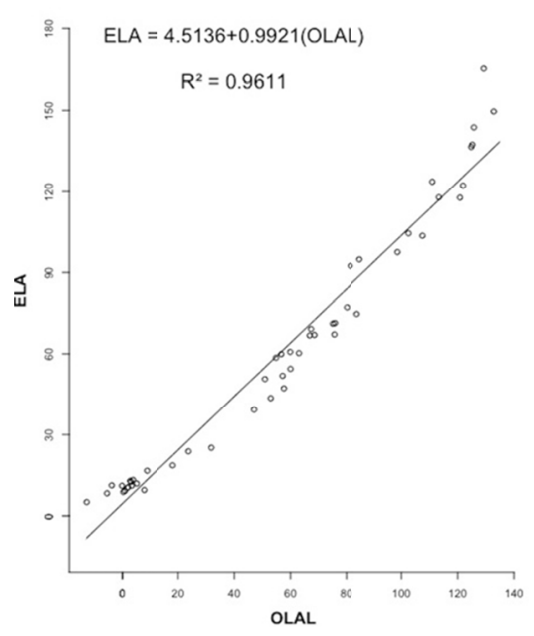

D

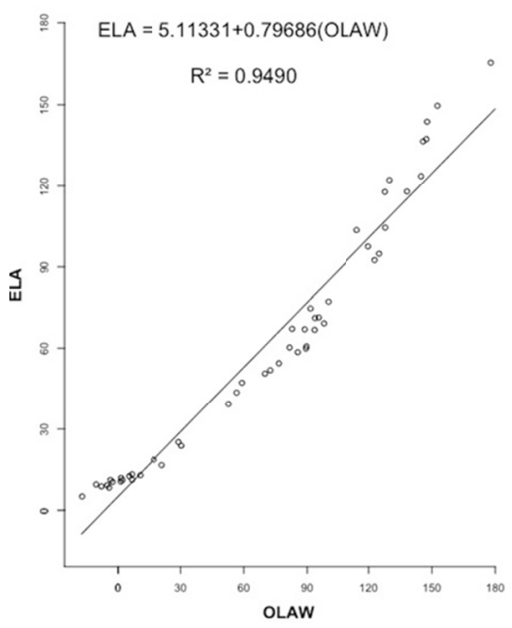

G

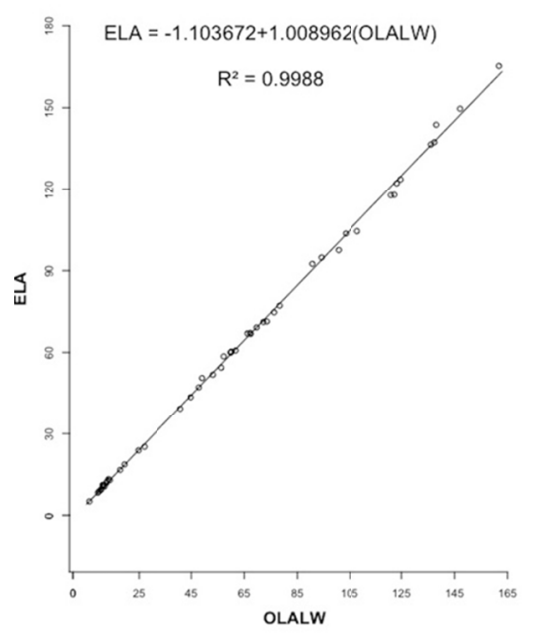

B

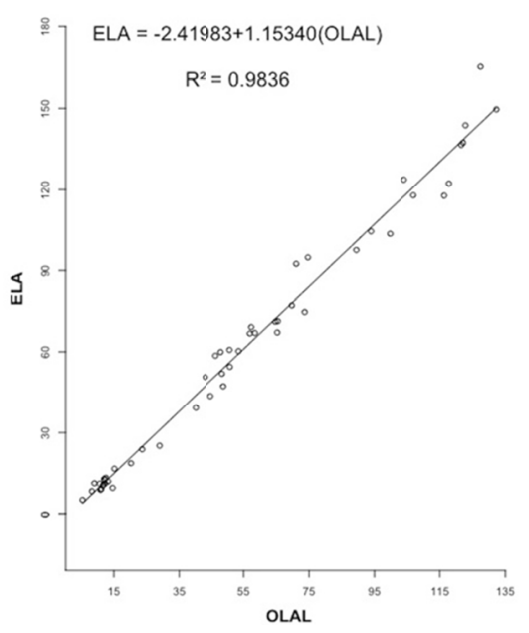

E

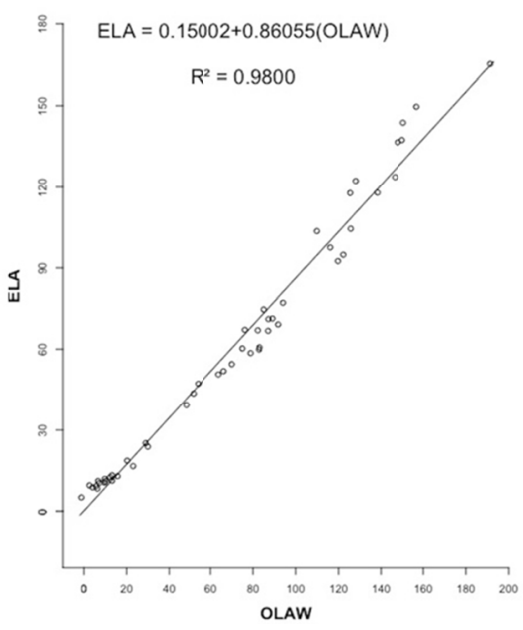

$\mathrm{H}$

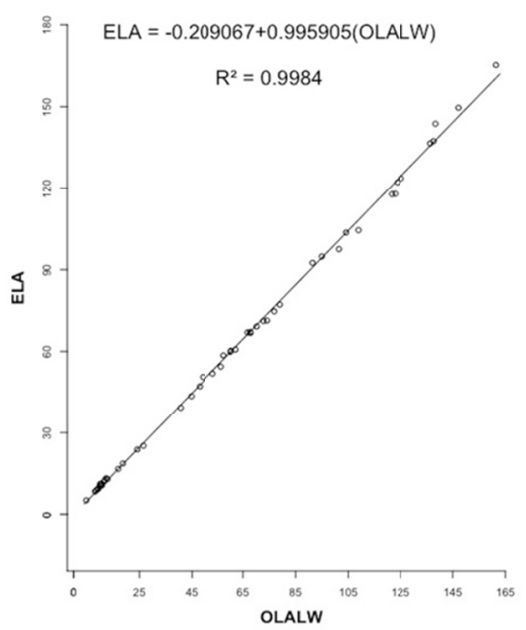

C

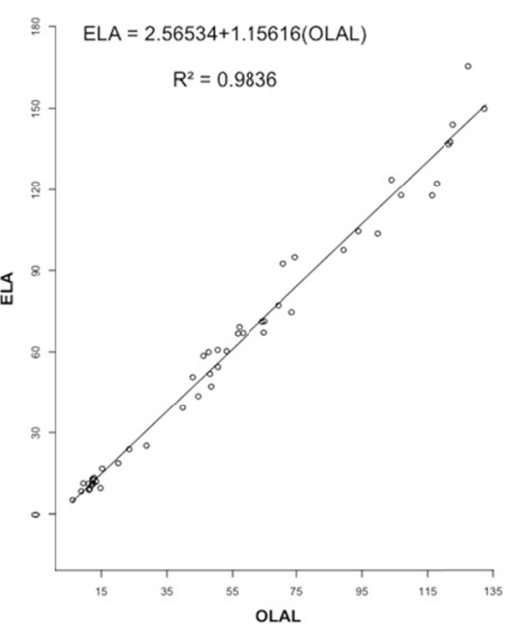

F

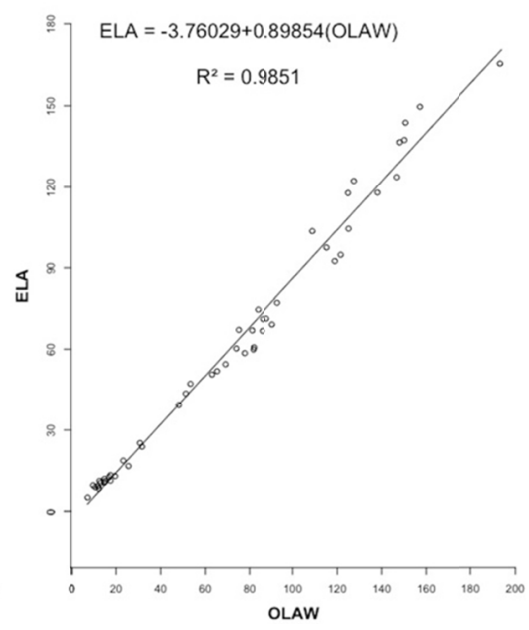

I

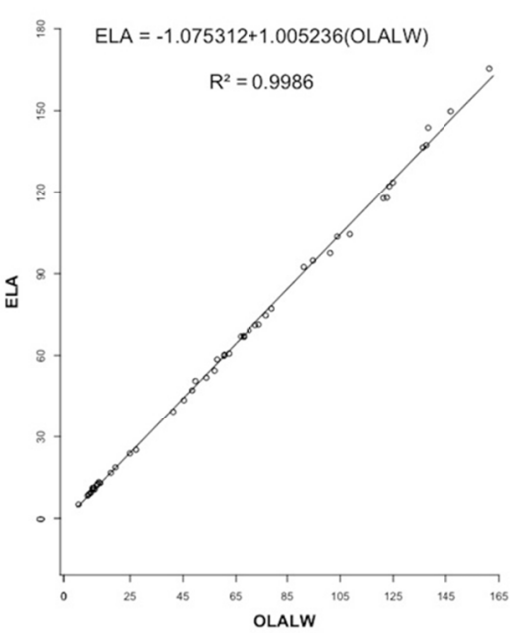


$J$

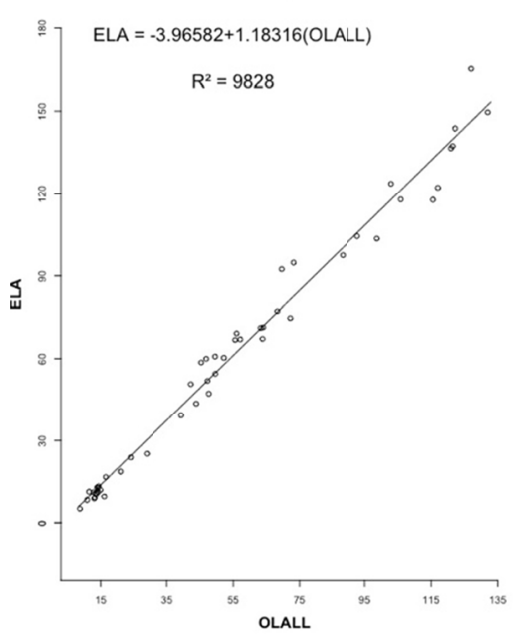

M

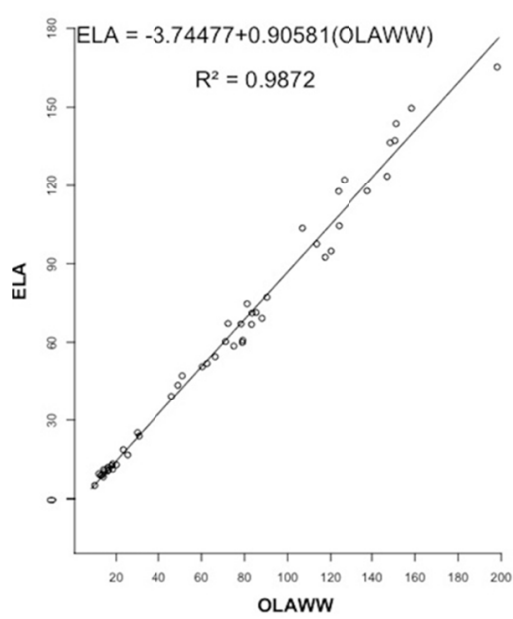

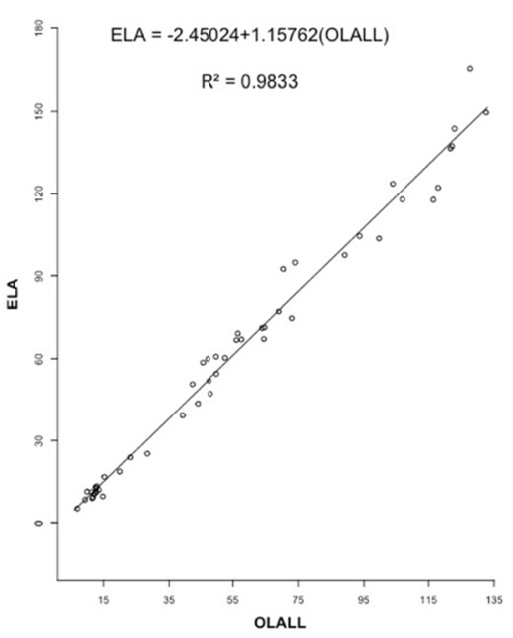

N

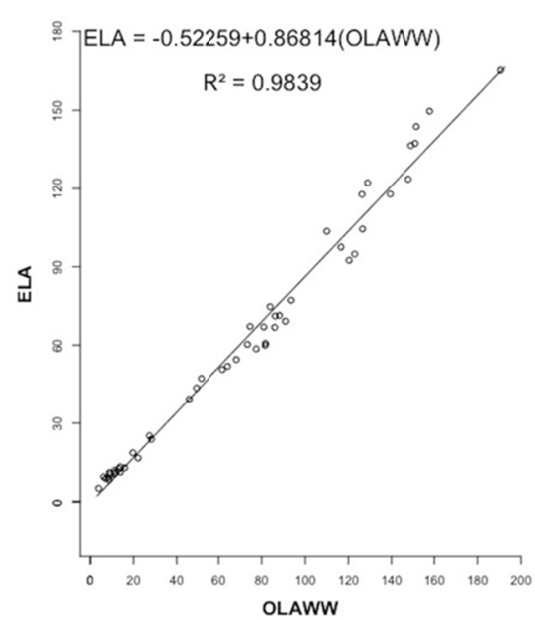

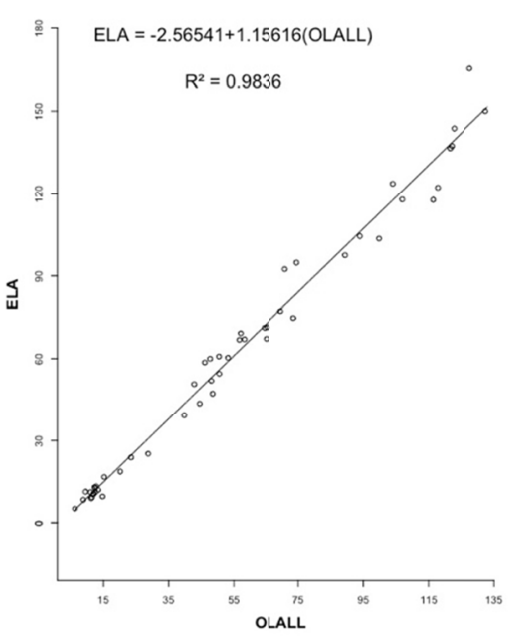

$\mathrm{O}$

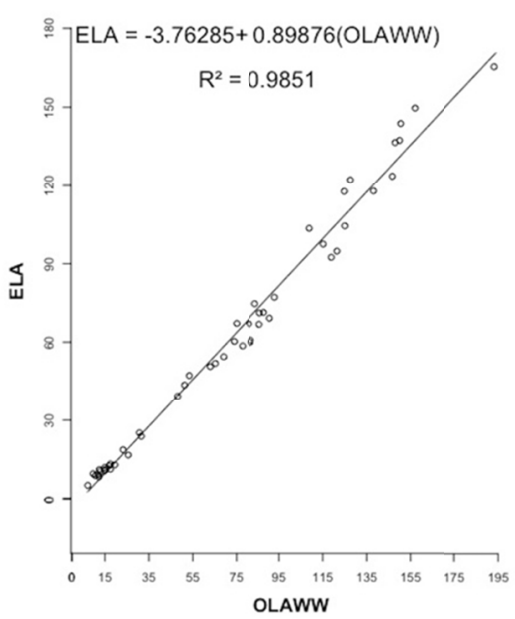

Figure 2. First degree linear adjustment validation equation and its respective determination coefficient $\left(\mathrm{R}^{2}\right)$ using the estimated leaf area (ELA) as the dependent variable obtained by first degree linear modeling equations (A, D, G, J and M), quadratic (B, E, H, K and N) and power (C, F, I, L and O), as a function of leaf length observed (OLAL), width (OLAW), length product with width (OLALW), length product with length (OLALL) and width product with width (OLAWW) of Artocarpus heterophyllus leaf

All OLA and ELA values, did not differ statistically by Student's t-test at $5 \%$ probability (Table 3 ). However, it should be emphasized that higher values indicate greater similarity between OLA and ELA, so the equations taking into account LW as independent variable were shown to be more interesting with values close to each other, and higher than the others. These same equations also present MAE and RMSE values closer to zero, however, the first-order linear model equation was slightly higher, attesting greater precision of the fit.

In all cases using only a linear dimension (L, W, LL or WW) with independent variable, good adjustments were not obtained with high values of MAE and RMSE. In practice, making the measurement of only one of the dimensions of the sheet is less exhausting, making the job easier. Adjustment using only one measure have already been described by Campostrini and Yamanishi (2001) and Schmildt et al. (2016) for Carica papaya L. and Passiflora mucronata based on the length of the central rib as independent variable. However, according to Espindula et al. (2018), these models are less accurate for most species and should only be used in particular cases.

Thus, as found in the present study, equations that combine more than one linear measure are more desirable, to estimate the leaf area of Artocarpus heterophyllus, presenting better adjustments. LW based adjustment as an independent variable were also observed for Vitis vinifera L. (Montero et al., 2000; Buttaro et al., 2015), Vicia 
faba L. (Peksen, 2007), Coffea canephora (E. R. Schmildt, Amaral, Santos, \& O. Schmildt, 2015) and Litchi chinensis Sonn (Oliveira et al., 2017).

Table 4. Observed leaf area (OLA) and estimated leaf area (ELA) of linear equations of first degree, quadratic and potential for the independent variables length (L), width (W) and product of length and width (LW) product of length with length (LL) and product of width with width (WW), besides the value of $p$, mean absolute error (MAE) and root mean square error (RMSE) of Artocarpus heterophyllus leaves used for validation

\begin{tabular}{|c|c|c|c|c|c|c|}
\hline Model & Variable & OLA & ELA & $p^{*}$ value & MAE & RMSE \\
\hline Linear & $\mathrm{L}$ & & 56.4983 & 0.6559 & 7.7063 & 9.9252 \\
\hline Linear & W & & 69.5898 & 0.3798 & 15.9558 & 17.865 \\
\hline Linear & LW & & 61.1224 & 0.9515 & 1.3318 & 1.7571 \\
\hline Linear & LL & & 54.5424 & 0.4775 & 8.0189 & 11.0625 \\
\hline Linear & WW & & 70.9989 & 0.2803 & 10.6452 & 12.6620 \\
\hline Quadratic & $\mathrm{L}$ & & 54.60942 & 0.4871 & 7.0398 & 10.3483 \\
\hline Quadratic & W & 60.5666 & 70.2065 & 0.3311 & 11.3116 & 13.8093 \\
\hline Quadratic & LW & & 61.0255 & 0.9602 & 1.3351 & 1.8890 \\
\hline Quadratic & LL & & 54.4363 & 0.4738 & 7.3154 & 10.5619 \\
\hline Quadratic & WW & & 70.3681 & 0.3212 & 10.4575 & 13.3934 \\
\hline Power & $\mathrm{L}$ & & 54.6048 & 0.4863 & 7.1264 & 10.4090 \\
\hline Power & W & & 71.5906 & 0.2559 & 11.2491 & 13.4760 \\
\hline Power & LW & & 61.3208 & 0.9343 & 1.4224 & 1.9138 \\
\hline Power & LL & & 54.6049 & 0.4863 & 7.1263 & 10.4090 \\
\hline Power & WW & & 71.5750 & 0.2565 & 11.2339 & 13.4590 \\
\hline
\end{tabular}

Note. $* P$ values higher than 0.05 indicate that the observed leaf area (OLA) and the estimated leaf area (ELA) do not differ by Student t-test.

Thus, considering the values of MAE and RMSE, besides the non-significant values of the comparison between ELA and OLA, as well as the highest value of $\mathrm{R}^{2}$ of the validation equation, the first degree linear model based on the product of length and width (LW ) as an independent variable represented by the behavior shown in Figure 3, showed to be more accurate, showing an excellent relation between the foliar area observed and the estimated leaf area, as well as the normal distribution of the residues, which can be used to estimate the leaf area of jackfruit with a high degree of accuracy non-destructively.

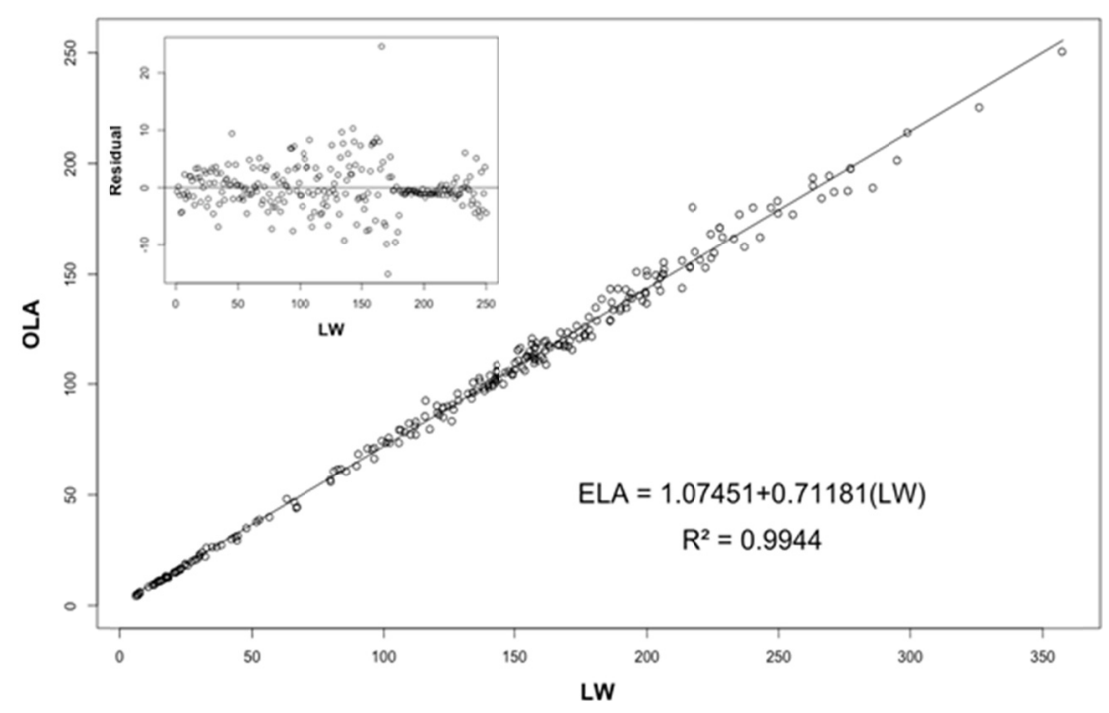

Figure 3. Linear equation of first degree, coefficient of determination $\left(\mathrm{R}^{2}\right)$ and residual, using the foliar area observed (OLA) as dependent variable, as a function of the product of the length and width (LW) of Artocarpus heterophyllus leaf 


\section{Conclusion}

The jackfruit (Artocarpus heterophyllus) leaf area estimate can be measured quickly, accurately and non-destructively by the first degree linear model based on the product of length and width (LW) as an independent variable, following the equation ELA $=1.07451+0.71181(\mathrm{LW})$.

\section{Acknowledgements}

CNPq, CAPES and FAPES for financial support.

\section{References}

Antunes, W. C., Pompelli, M. F., Carretero, D. M., \& Damatta, F. M. (2008). Allometric models for non-destructive leaf area estimation in coffee (Coffea arabica and Coffea canephora). Annals of Applied Biology, 153(1), 33-40. https://doi.org/10.1111/j.1744-7348.2008.00235.x

Borghezan, M., Gavioli, O., Pit, F. A., \& Silva, A. L. (2010). Modelos matemáticos para a estimativa da área foliar de variedades de videira à campo (Vitis vinifera L.). Ciência Técnica e Vitivinicola, 25(1), 1-7.

Buttaro, D., Rouphael, Y., Rivera, C. M., Colla, G., \& Gonnella, M. (2015). Simple and accurate allometric model for leaf area estimation in Vitis vinifera L. genotypes. Photosynthetica, 53(3), 342-348. https://doi.org/10.1007/s11099-015-0117-2

Blanco, F. F., \& Folegatti, M. V. (2005). Estimation of leaf area for greenhouse cucumber by linear measurements under salinity and grafting. Scientia Agricola, 62(4), 305-309. https://doi.org/10.1590/S010390162005000400001

Campostrini, E., \& Yamanishi, O. K. (2001). Estimation of papaya leaf area using the central vein length. Scientia Agricola, 58(1), 39-42. https://doi.org/10.1590/S0103-90162001000100007

Costa, A. P., Pôças, I., \& Cunha, M. (2016). Estimating the leaf area of cut roses in different growth stages using image processing and allometrics. Horticulturae, 2(6), 1-10. https://doi.org/10.3390/horticulturae2030006

Espindula, M. C., Passos, A. M. A., Araújo, L. F. B., Marcolan, A. L., Partelli, F. L., \& Ramalho, A. R. (2018). Indirect estimation of leaf area in genotypes of 'Conilon' coffee (Coffea canephora Pierre ex A. Froehner). Australian Journal of Crop Science, 12(6), 990-994. https://doi.org/10.21475/ajcs.18.12.06.PNE1090

Fascella, G., Darwich, S., \& Rouphael, Y. (2013). Validation of a leaf area prediction model proposed for rose. Chilean Journal of Agricultural Research, 73(1), 73-76. https://doi.org/10.4067/S0718-58392013000 100011

Ferreira, E. B., Cavalcanti, P. P., \& Nogueira, D. A. (2018). Package 'ExpDes.pt'.

Köppen, W. (1936). Das geographische system der klimate. In G. W. Köppen, \& M. R. Geiger (Eds.), Handbuch der Klimatologie. Berlin: Gebrüder Bornträger.

Levine, D. M., Stephan, D. F., \& Szabat, K. A. (2017). Estatistic for managers using Microsoft Excel: Global edition (8th ed., p. 728). London: Person.

Montero, F. J., Juan, J. A., Cuesta, A., \& Brasa, A. (2000). Non destructive Methods to Estimate Leaf Area in Vitis vinifera L. Hort Science, 35(4), 696-698. https://doi.org/10.21273/HORTSCI.35.4.696

Morgado, M. A. D. O., Bruckner, C. H., Rosado, L. D. S, Assunção, W., \& Santos, C. E. M. (2015). Estimação da área foliar por método não destrutivo, utilizando medidas lineares das folhas de espécies de Passiflora1. Revista Ceres, 60(5), 662-667. https://doi.org/10.1590/S0034-737X2013000500009

Oliveira, L. F., Godoy, R. L. O., Borges, S. V. (2011). Qualidade de jaca (Artocarpus heterophyllus, Lam.) desidratada sob diferentes condicões de processo. Brazilian Journal of Food Technology, 14(3), 241-248. https://doi.org/10.4260/BJFT2011140300029

Oliveira, P. S., Silva, W., Costa, A. A. M., Schmildt, E. R., \& Vitória, E. L. (2017). Leaf area estimation in litchi by means of allometric relationships. Revista Brasileira de Fruticultura, 39(Special), 1-6. https://doi.org/ $10.1590 / 0100-29452017403$

Peksen, E. (2007). Non-destructive leaf area estimation model for faba bean (Vicia faba L.). Scientia Horticulturae, 113(4), 322-328. https://doi.org/10.1016/j.scienta.2007.04.003

Perdomo, M., \& Magalhães, L. M. S. (2007). Acão alelopática da jaqueira (Artocarpus heterophyllus) em laboratório. Floresta e Ambiente, 14(1), 52-55. 
Pezzini, R. V., Cargnelutti Filho, A., Alves, B. M., Follmann, D. N., Kleinpaul, J. A., Wartha, C. A., \& Silveira, D. L. (2018). Models for leaf area estimation in dwarf pigeon pea by leaf dimensions. Bragantia, 77(2), 221-229. https://doi.org/10.1016/j.scienta.2007.04.003

Pimentel-Gomes, F. (2009). Curso de estatística experimental (15th ed.). Piracicaba, SP: Fealq.

Pompelli, M. F., Antunes, W. C., Ferreira D. T. R. G., Cavalcante, P. G. S., Wanderley Filho, H. C. L., \& Endres, L. (2012). Allometric models for non-destructive leaf area estimation of Jatropha curcas. Biomass and Bioenergy, 36, 77-85. https://doi.org/10.1016/j.biombioe.2011.10.010

R Core Team. (2018). R: A language and environment for statistical computing. Vienna: R Foundation for Statistical Computing, Vienna, Austria.

Schindelin, J., Rueden, C. T., Hiner, M. C., \& Eliceiri, K. W. (2015). The ImageJ Ecosystem: An Open Platform for Biomedical Image Analysis. Molecular Reproduction and Development, 82, 7-8, 518-529. https://doi.org/10.1002/mrd.22489

Schmildt, E. R., Amaral, J. A. T., Santos, J. S., \& Schmildt, O. (2015). Allometric model for estimating leaf area in clonal varieties of coffee (Coffea canephora). Revista Ciência Agronômica, 46(4), 740-748. https://doi.org/10.5935/1806-6690.20150061

Schmildt, E. R., Oliari, L. S., Schmildt, O., Alexandre, R. S., \& Pires, F. R. (2016). Determinação da área foliar de Passiflora mucronata a partir de dimensões lineares do limbo foliar. Revista Agro@mbiente On-line, 10(4), 351-354. https://doi.org/10.18227/1982-8470ragro.v10i4.3720

Vitória, E. L., Freitas, I. L. J., Locatelli, T., Lacerda, E. G., Valle, J. M., Pereira, R. C., ... Fernandes, A. A. (2018). Mathematical Models for Leaf Area Estimates of Guava. Journal of Agricultural Science, 10(12), 272-278. https://doi.org/10.5539/jas.v10n12p272

\section{Copyrights}

Copyright for this article is retained by the author(s), with first publication rights granted to the journal.

This is an open-access article distributed under the terms and conditions of the Creative Commons Attribution license (http://creativecommons.org/licenses/by/4.0/). 